\section{Marine Biology}

August 2008, Volume 155, Number 2 : Pages 147-

157

http://dx.doi.org/10.1007/s00227-008-1013-0

(c) 2008 Springer. Part of Springer Science+Business

Media

The original publication is available at http://www.springerlink.com
Archimer, archive institutionnelle de l'Ifremer http://www.ifremer.fr/docelec/

\title{
Genetic structure at different spatial scales in the pearl oyster ( Pinctada margaritifera cumingii ) in French Polynesian lagoons: beware of sampling strategy and genetic patchiness
}

\author{
Sophie Arnaud-Haond ${ }^{1,4}{ }^{*}$, V. Vonau ${ }^{1}$, C. Rouxel ${ }^{1}$, F. Bonhomme ${ }^{3}$, Jean Prou $^{1}$, E. Goyard ${ }^{1}$ and P. \\ Boudry $^{2}$
}

\footnotetext{
${ }^{1}$ Laboratoire d'Aquaculture tropicale, IFREMER/COP, IFREMER, BP 7004, 98719 Taravao, Tahiti, French Polynesia, France

${ }^{2}$ Laboratoire de Génétique et Pathologie, IFREMER, BP 133, 17390 La Tremblade, France

${ }^{3}$ Département de Biologie Intégrative, Institut des Sciences de L'Evolution de Montpellier (ISEM) UMR 5554, Station Méditerranéenne de l'Environnement Littoral, 34200 Sète, France

${ }^{4}$ Present address: Laboratoire Environnement Profond, Centre de Brest, IFREMER, BP 70, 29280 Plouzané, France
}

*: Corresponding author : Sophie Arnaud-Haond, email address : sarnaud@ifremer.fr

\begin{abstract}
:
In order to study further the genetic structure of the pearl oyster Pinctada margaritifera in French Polynesia with a special consideration for the sampling scale, we analyzed or re-analyzed sets of data based on nuclear DNA markers obtained at different spatial scales. At a large scale (several $1,000 \mathrm{~km}$ ), the remote Marquesas Islands were confirmed to be significantly differentiated from Tuamotu-Gambier and Society archipelagos, with a marked difference however for the two main islands that are different from each other. At a medium scale (several 10 to several $100 \mathrm{~km}$ ), overall homogeneity was observed within and between these two archipelagos, with some exceptions. This could be attributed both to large-scale larval dispersal and to human-driven spat translocations due to pearl oyster cultivation. These results contrast with those observed (1) at a small scale (less than $10 \mathrm{~km}$ ) in a lagoon heavily impacted by translocation and cultural practices, where significant genetic differentiation was detected among three laying beds, and (2) at a micro scale where we detected an important variability of the genetic composition of young spat recruited on artificial collectors. Such patterns could result from a high variance in the number of genitors at the origin of each cohort, or from pre- or post-settlement selection on linked loci. Altogether, our data support the hypothesis that under certain conditions populations of bivalves may exhibit patterns of chaotic genetic patchiness at local scale, in line with the increasing report of such patchiness in marine benthic organisms. This underlines the importance of sampling scale that should be rigorously defined depending on the questions to be answered. Nevertheless, a survey of about 80 articles dealing with population genetics of marine invertebrates showed that only $35 \%$ of those studies disclosed details about the sampling strategy (particularly the area explored). These results emphasize the need for cautious interpretation of patterns of genetic structure at medium scale when rigorous sampling strategies are not deployed.
\end{abstract}

Keywords: genetic patchiness; sampling strategy; benthic organisms; pearl oyster; bivalve; Polynesia; population genetics 


\section{Introduction}

54 Genetic homogeneity over large geographic scales has been long expected, and 55 sometimes observed, due to adult or larval mobility and to the absence of physical barriers 56 to dispersal (Vermeij 1987). A large number of marine invertebrates exhibit large 57 population sizes, external fertilization, high fecundity, an extensive pelagic larval phase, 58 and a benthic adult stage. These characteristics lead us to an expectation of Hardy-

59 Weinberg equilibrium as well as low genetic divergence, due to extensive gene flow 60 during the larval stage, whereas the low mobility at the adult stage may favor local 61 adaptation at the latest life stages.

63 Studies of the distribution of genetic variability of the black-lipped pearl oyster, 64 Pinctada margaritifera from the Central Pacific, performed on samples collected in the 65 1980's, suggested a natural pattern of restriction to gene flow at both large (more then $661000 \mathrm{~km}$ ) and medium scales (200 to $400 \mathrm{~km}$ ). For example, populations from the Society 67 archipelagos are significantly differentiated, although separated by less than $200 \mathrm{~km}$ 68 (Arnaud-Haond et al. 2003a). Previous studies, based on allozymes, even suggested the 69 possible existence of genetically differentiated laying beds coexisting within the atoll of

70 Takapoto (Blanc et al. 1985; Durand and Blanc 1986). However, studies performed on 71 more recent samples showed homogenization of genetic pools of the archipelagos of 72 Society and Tuamotu-Gambier (Arnaud-Haond et al. 2004). At the archipelago scale, this 73 homogenization was attributable to the massive spat translocation in that area during 74 1990s. At the intra archipelago scale, within the Tuamotu-Gambier archipelago, where few 75 samples were analyzed before the translocation events, it is more difficult to distinguish 76 between the hypothesis of extensive natural gene flow at small spatial scale (several tens 77 of kilometers) and the hypothesis of artificial gene flow linked to farming practices 
78 (Arnaud-Haond et al. 2003b). In any event, further screening of isolated islands should be

79 performed to identify possibly still divergent natural populations in atolls where no pearl

80 culture is developed or no translocation has been performed, and which may represent

81 interesting genetic resources in the perspective of future hatchery produced stock and

82 selection programs. For P. margaritifera, at the intra lagoon spatial scale, as for other

83 sessile species presenting pelagic larval stage (Roughgarden et al. 1988; Gaines and

84 Bertness 1992), a very stochastic dynamic of spat recruitment has been reported in both

85 space and time (Friedman et al. 1998; Friedman and Bell 1999). Whether this chaotic

86 pattern is accompanied by spatial or temporal variance in the genetic composition of spat

87 is still not known. Although no such data exist on $P$. maxima recruitment, some genetic

88 data suggest the occurrence of localized heterogeneity in the genetic constitution of

89 recruits, interpreted by the authors as resulting from large variance in the local

90 reproductive success (Benzie and Smith-Keune 2006). Recent studies on P. margaritifera

91 showed no significant difference in the genetic variability of wild samples and spat-

92 collected samples from farms (Arnaud-Haond et al. 2003b). To what extent this

93 observation reflects high genetic variability of locally collected spat, or high genetic

94 variability of admixtures of distinct groups of collected spats in farms remains to be

95 determined.

In benthic species for which migration is restricted to the larval stage, most species

98 with lecithotrophic larvae exhibit more restricted gene flow compared with those with

99 planctotrophic larvae, who remain longer in the plankton (Hunt 1993; Hellberg 1996;

100 Poulin and Féral 1996; Hoskin 1997; Arndt and Smith 1998; Bonhomme and Planes

101 2000). However, in several invertebrate species that show substantial larval dispersal

102 capability and large-scale genetic homogeneity, small-scale spatial and temporal genetic 
103 patchiness has been reported (Johnson and Black 1984; Watts et al. 1990; David et al.

104 1997b; Johnson and Wernham 1999). The hypotheses invoked to explain such sub-

105 structure of populations at small scale include both pre- or post-settlement selection of 106 genotypes, as well as the different genetic origins of settling larvae (Johnson and Black

107 1982; Johnson and Black 1984; David et al. 1997a; David et al. 1997b) due to the

108 stochastic recruitment in the sea (Roughgarden et al. 1988; Gaines and Bertness 1992).

109 High variance in reproductive success, implying low effective number of genitors at the

110 origin of a cohort, have already been reported in bivalves (Hedgecock 1994; Li and

111 Hedgecock 1998; Boudry et al. 2002) and may favor the occurrence of genetically distinct

112 pools of recruits at small geographic or temporal scales. A complementary explanation is

113 the occurrence of differential selection in space and time favoring genetic differentiation of

114 recruited cohorts. This hypothesis requires a strong genetic linkage between the markers

115 used and some fitness component. The occurrence of post-settlement selection hypothesis

116 was supported in Littorina saxatilis (Johannesson et al., 1995), and pre-settlement

117 selection hypothesis has never been tested due to the technical difficulties in isolating and 118 scoring very young larvae. It is therefore hard to distinguish between the hypotheses of 119 distinct genetic origin of recruits: the synthesis of both hypotheses can be summarized as 120 the "recruitment history" (Johnson and Black 1984; Watts et al. 1990; David et al. 1997b;

121 Johnson and Wernham 1999). The existence of mosaic patterns at small scale, independent 122 of the possible large scale homogeneity of population and gene flow among distant sites, 123 underlines the importance of sampling scale for population genetics and biogeographic 124 studies (Benzie 2000). The collection of samples representative of the populations studied 125 is a pre-requisite to the interpretation of data in terms of gene flow, and may be influenced 126 by the scale of sample collection compared to the area where the species collected is 127 locally distributed. Yet, for most species studied so far, the difficulty of access to marine 
128 environments and the lack of knowledge of the existence and scale of possible genetic

129 patchiness often hamper the application of a strict sampling strategy. In this context, the

130 interpretation of population genetics data in terms of gene flow may therefore often be a

131 difficult and risky exercise (Johanesson et al., 1995).

132

133 We used four anonymous nuclear markers to assess the pattern of genetic structure of the

134 Polynesian black-lipped pearl oyster populations at four spatial scales: among 135 archipelagos, among islands within archipelagos, among distinct sampling sites within an 136 island, and among artificial spat collectors within sampling sites. We addressed the 137 following questions: 1) At large and medium scale, among archipelagos and among islands 138 within archipelagos, can some genetically divergent populations still be detected in 139 isolated or non harvested atolls? 2) When sampled at micro-scale, do P. margaritifera 140 laying beds exhibit genetic heterogeneity? , 3) what are the possible consequences of 141 genetic patchiness for sampling strategy in population genetics and biogeographic studies? 


\section{Material and Methods}

\subsection{Sample collection and DNA extraction}

$148 \quad$ For large and medium-scale analysis, wild samples from fifteen geographic lagoons

149 in French Polynesia, ranging from the western Society (Manuae) to the South-Eastern

150 Tuamotu-Gambier (Mangareva) and the Northern Marquesas (Nuku-Hiva) were sampled by

151 SCUBA-diving during 1999-2002 (Figure 1; Figure 2; Table 1). When possible, samples

152 were collected in areas as large as possible, encompassing different laying beds, in order to

153 collect a sample as representative as possible of the population studied. Details of the area

154 encompassed by sampling are given in Table1 when available. Considering the difficulties in

155 gathering samples from so many dispersed islands, we were able to get some samples thanks

156 to the kindness of inhabitants, and information as to the detailed sampling area was not

157 always possible to obtain. Eight of the fifteen samples (Manuae, Maupihaa, Arutua, Apataki,

158 Manihi, Takaroa, Mangareva and Hiva Oa) have already been analyzed for all nuclear

159 markers in recent studies (Arnaud-Haond et al. 2003a; Arnaud-Haond et al. 2004).

160 Small-scale study was performed within Takapoto lagoon (Tuamotu-Gambier): wild

161 samples from three distinct zones were sampled by diving in May 2002 (Figure 2; Table 1),

162 each in restricted areas of several $\mathrm{m}^{2}$ in order to avoid mixing distinct beds. Finally, six spat 163 samples of 42 to 50 individuals each were collected in February 2002 in three distinct

164 collection stations (Figure 2; Table 1), representing different levels of spat density (high 165 density and homogeneous distribution of spat on the station and collectors, mid-density and 166 relative homogeneity, very low density and heterogeneity). 
A piece of adductor muscle or gill (Raroïa) was removed from each specimen and

168 preserved in $80 \%$ ethanol. The procedure of DNA extraction, precipitation and storage were similar to those described in Sambrook et al. (1989); we used approximately $0.5 \mathrm{~g}$ of 170 chopped and subsequently air-dried tissue. The nucleic acid pellet obtained after

171 precipitation in $100 \%$ ethanol was washed with $70 \%$ ethanol, air-dried, resuspended in 100

172 to $200 \mu \mathrm{l}$ of deionised water and preserved at $-20^{\circ} \mathrm{C}$. DNA concentrations, obtained by

173 fluorimetry, were found to be about 300ng/ $\mu 1$.

174

2.3. Genetic diversity analyses, Hardy Weinberg equilibrium, linkage disequilibrium and genetic structure 
Genetic diversity within populations was estimated by unbiased $\left(\mathrm{H}_{\mathrm{nb}}\right)$ and observed

$193\left(\mathrm{H}_{\mathrm{obs}}\right)$ gene diversity (Nei 1987). We estimated the overall values for the inbreeding 194 coefficient $\left(F_{\text {is }}\right)$ as described by Weir and Cockerham (1984) and we used a permutation 195 procedure (1000 permutations) to test whether a particular $F_{\text {is }}$ value was significantly 196 different from 0. The two-locus correlation coefficient R2 (Weir 1979) was estimated with 197 the procedure of Black and Krafsur (1985), and its departure from zero was tested by a 198 permutation approach.

199 Genetic differentiation $\left(\mathrm{F}_{\mathrm{st}}\right)$ was estimated between pairs of populations with the 200 estimator $\theta$ of Weir \& Cockerham (Weir and Cockerham 1984). The significance of the $\theta$ 201 values was tested by randomly permuting $3000 \mathrm{X}$ the individuals between samples. Those 202 calculations were performed using the GENETIX 4 package (Belkhir et al. 1996-2001).

\subsection{Variance of allelic frequencies}

206 In order to estimate the effective number of genitors at the origin of each spat 207 sampled, the standardized variance in allele frequency change was estimated according to 208 the theory of selectively neutral alleles in finite populations (Waples 1989):

$$
\hat{\mathrm{F}}_{k}=\frac{1}{k-1} \sum_{i=1}^{k} \frac{\left(x_{i}-y_{i}\right)^{2}}{\left(x_{i}+y_{i}\right) / 2}
$$

209

210 Where $\mathrm{k}$ is the number of alleles and $\mathrm{x}_{\mathrm{i}}$ and $\mathrm{y}_{\mathrm{i}}$ the allelic frequencies of the $\mathrm{i}^{\text {th }}$ of $\mathrm{k}$ alleles. A 211 mean $\mathrm{F}_{\mathrm{k}}$ across loci was weighted by the number of alleles at each locus, and $\mathrm{N}_{\mathrm{e}}$ was 212 estimated using the formula:

$213 \quad \hat{N}_{e}=\frac{t}{2\left[F_{k}-\left(1 / 2 n_{o}\right)-\left(1 / 2 n_{t}\right)\right]}$ 
215 where $t$ is the number of generations (we assumed one generation separated the spat from the

216 putative pool of genitors), $\mathrm{n}_{\mathrm{o}}$ the sample size at the generation 0 and $\mathrm{n}_{\mathrm{t}}$ the sample size at the

217 generation t. The confidence interval at $95 \%$ is estimated as:

$218 \quad\left[\frac{n \hat{F}}{\chi^{2}{ }_{\alpha / 2[n]}} ; \frac{n \hat{F}}{\chi^{2}{ }_{1-\alpha / 2[n]}}\right]$

219 The estimation was made using the software NeEstimator (Peel et al. 2004) with all putative

220 genetic pools of genitors: each of the three wild samples from Takapoto, the synthetic

221 population obtained while pooling these three samples, and the synthetic population obtained

222 while pooling the four samples from Tuamotu (Arutua, Apataki, Manihi and Takaroa).

\subsection{Literature screening}

A general search was performed in ISI (Web of Science) for the keywords [(“"population

228 genetics" OR "genetic structure") and (benthic OR "marine invertebrate" OR "mollusks"

229 OR "echinoderm" OR "bivalve" OR "gastropods")], which returned a list of 170 published

230 studies. Although we were aware that this does not represent an exhaustive sampling of the

231 existing work, we considered that this 'sampling strategy' was able to deliver a

232 representative sample of the existing literature. Among those, 88 were found to actually

233 deal with population genetics or biogeography of benthic organisms and 66 could be

234 gathered and screened for details of sampling strategy. Information retained was classified

235 as follows: A) as for the area explored 1/no information disclosed, 2/ details given 236 about the area explored for each site and B) as for the strategy for choosing samples 3/ 237 mention of the strategy as "random or haphazard" 4/ exhaustive sampling 5/ else when 
238 samples collected were chosen according to a particular strategy such as the use of a 239 transect or a grid.

240

241 


\section{Results}

\subsection{Level of genetic variability, Hardy Weinberg equilibrium, linkage disequilibrium}

The level of unbiased gene diversity $\mathrm{H}_{\mathrm{nb}}$ ranged between 0.30 (Manuae) and 0.45

249 (Kauehi) in natural laying beds, where the number of alleles was of 2.5 (Hao) to 5

250 (Hereheretue), and on collectors, the heterozygosity ranged from 0.29 to 0.40 and the 251 number of alleles from 3.5 to 4.00 (Table 1).

252 Significant heterozygote deficiency values were observed in four of the six 253 collector samples, and in five of the eighteen samples from natural laying beds (Table 1).

in one sample from natural population: Takapoto 3. All the remaining significant values concerned samples from spat collectors, and locus pinucl2: with pinucl3 for collector 3 and 4, with pinaldo for collectors 2 and 3, and with pinU4 for collectors 5 and 6 .

\subsection{Pairwise genetic differentiation}

260 For samples from wild laying beds, pairwise genetic differentiation was analyzed at 261 three geographic scales, among lagoons among archipelagos, among lagoons within 262 archipelagos, and within lagoon. At the among archipelagos scale, despite the inclusion of 263 samples from remote atolls from Tuamotu-Gambier that supposedly received no income of 264 spat, no significant genetic differentiation was detected between the Society and Tuamotu 265 archipelagos. As for the samples from the Marquesas archipelagos, the sample from Hiva 266 Oa was significantly different from all other samples, except the ones from Makemo and 
267 Hao. The sample from Nuku-Hiva, despite being more northern (but less eastern), was less 268 differentiated from samples from the Northern Tuamotu-Gambier, but remained distinct 269 from the southern part of the archipelago (Hereheretue, Marutea and Mangareva), and 270 Society samples. At the within-archipelago scale, despite the inclusion of samples from 271 remote atolls the values of $F_{\text {st }}$ between pairs of samples for the nine wild populations from 272 Tuamotu-Gambier were very low, and most were null (Table 4). The significant values 273 mostly reflected the differentiation of the sample from the very isolated atoll of 274 Hereheretue (Tuamotu-Gambier), one sample from the center of Tuamotu-Gambier 275 (Makemo) as well as two samples from southern Tuamotu-Gambier (Marutea and 276 Mangareva). The differentiation between the northern sample from Arutua (Northern 277 Tuamotu-Gambier) and the samples from Takapoto3 and Marutea (Southern Tuamotu278 Gambier) is also noteworthy. Finally, at the within-lagoon scale, Takapoto 1 and 3 are 279 significantly differentiated from each other, despite being the geographically nearest 280 samples and not showing any significant differentiation with the remote sample of 281 Takapoto 2.

282 As for the collectors, more differentiation is observed, particularly for the collector 283 1, which is almost completely differentiated from all the other samples from laying beds or 284 collectors from Takapoto (except collector 6), and from most samples from other Tuamotu 285 islands. Collector 4, 3 and 6 are respectively differentiated of one (Takapoto 3), two 286 (Takapoto 2 and 3) and all three samples from Takapoto natural population, whereas all 287 collectors from 2 to 6 are not different one from the others, and not significantly different 288 from any other Tuamotu samples. 
290

291

292

293

294

295

296

297

298

299

300

301

302

303

304

305

306

307

308

309

310

\subsection{Variance in allelic frequencies and estimation of the effective number of genitors.}

The effective number of genitors estimated for each collector was low in any case, being estimated by considering as a putative mother population either : i) each of the three samples from Takapoto (from 3 to 93, except for one case with collector 2, for which no upper limit could be estimated if Takapoto 2 would be the origin of recruits), ii) the pool of those three samples (5 to 136), or iii) the pool of all other natural laying beds sampled in Tuamotu archipelago. However, significantly more important values can be observed while considering this last case (from 22 to $\infty$ ).

\subsection{Results of the literature survey}

Results of the literature survey are summarized in Figure 3. Among 66 articles screened about $65 \%$ did not report any indication as to the sampling area explored or distance among samples; among these none gave any indication of the strategy for choosing individuals (according some particular criteria like size for example), and only 8 of those $65 \%$ acknowledged a random or haphazard strategy for picking samples. Now, $35 \%$ of studies screened gave indication as to the area encompassed by sampling, or the distance among collected samples, and $90 \%$ of those documented studies also reported the strategy for picking up samples (17\% reported an exhaustive collection, $65 \%$ a random choice and $9 \%$ other kind of strategy such as sampling along a transect or in a grid). 


\section{Discussion}

313 Spatial distribution of genetic variability at large scale

314 At the large scale (more than $1500 \mathrm{~km}$ ), in agreement with previous studies

315 (Arnaud-Haond et al., 2003a; Arnaud-Haond et al., 2004), the Marquesas samples, and

316 particularly the one from Hiva Oa, display a significant level of differentiation with those

317 from the two other archipelagos, reaching 8 to $10 \%$ when comparing Hiva Oa with

318 Society samples. Genetic differentiation of Marquesas populations is also evident in other

319 species, and particularly well described for the surgeonfish Acanthurus triostegus (Planes

320 et al. 1996; Planes and Fauvelot 2002). Two main phenomena are commonly invoked to

321 explain this isolation. The first is the Marquesas countercurrent, which is regular

322 throughout the year and which is opposed by the South Equatorial current; this might

323 constitute a barrier preventing larval dispersal (Vermeij 1987; Planes and Fauvelot 2002).

324 A second possibility is the influence of glaciations and co-occurring sea level drops and 325 lagoon drainage (Paulay 1990), have led to extinction-recolonization of most inner-reef

326 species in the lagoons; whereas the Marquesas islands might have represented refugia for 327 some of those species. In the case of the pearl oyster, it is likely that populations persisted

328 in Marquesas during the glacial episodes, whereas extinction and post-glacial (re)

329 colonisation is suspected for other Polynesian archipelagos (Arnaud-Haond et al. 2003a).

330 Although no pattern of monophyletism of Marquesas haplotypes was observed with

331 mitochondrial DNA analysis (Arnaud-Haond et al. 2003a), the present data support

332 previous findings that suggest a present day restriction to gene flow that may be partly

333 attributed to the existence of current limiting exchange with other archipelagoes.

334 The distribution of genetic variation between the populations of the Tuamotu-

335 Gambier archipelago supports the proposition that very little genetic differentiation exists 
336 within this area. In part, this phenomenon probably reflects the occurrence of larval

337 dispersal during the three-week pelagic larval stage of P. margaritifera. Yet, it is also

338 partly attributable to the transfers practiced over the ten years preceding our last sampling

339 campaign (Arnaud-Haond et al. 2004). The interpretation of the results obtained in terms

340 of natural patterns of gene flow must then be performed with caution. Nevertheless, our

341 data suggest the existence of only a slight restriction to gene flow at a medium scale (more

342 than five hundred kilometers), and the occurrence of genetically differentiated stocks.

343 Indeed, some isolated atolls do exhibit indices of genetic differentiation, for example: the

344 atolls of Southern Tuamotu-Gambier (Marutea and Mangareva), and the isolated atoll of

345 Hereheretue (Southern Tuamotu-Gambier). Given the scale of sampling for those

346 populations (see Table 1), we are confident the samples are likely to be representative of

347 the populations inhabiting those islands, and structure observed reflects restriction to gene

348 flow rather than genetic patchiness.

349 It is striking that at the smaller scale, of less than $300 \mathrm{~km}$ (Table 4), much more 350 differentiation ( $20 \%$ of the sample pairs) is observed than at medium scale (Table $2 ; 8 \%$ of 351 the sample pairs). This discrepancy is however mostly driven by the genetic heterogeneity 352 of samples gathered in very restricted areas: the ones from collectors, and one of the three 353 Takapoto samples (Takapoto 3) that shows indices of slight differentiation with both 354 Arutua and Takapoto 1 samples. These findings support the occurrence of recruitment 355 patchiness at that scale, rather than long term and stable restriction to gene flow between 356 those sampling locations.

Spatial genetic heterogeneity of recruitment

359 Both biotic and abiotic factors have been proposed as possible sources of the 360 observed stochasticity as well as of the spatial and temporal patchiness of cohort recruits, 
361 but the factors that may explain the genetic patchiness are still unknown (Johnson and

362 Black 1984; Watts et al. 1990; McShane and Smith 1991; David et al. 1997a). The main

363 observations that can be retained from the collector data include (1) the positive

364 relationship between the spat density and its departure from HWE and (2) the negative

365 relationship between spat density and genetic differentiation. All spat samples from high

366 density collectors (C4, C5, C6) exhibit significant heterozygote deficiencies and linkage

367 disequilibrium, but are not significantly differentiated from most other samples. On the

368 other hand, two of the three spat samples from low-medium density collectors $(\mathrm{C} 1, \mathrm{C} 3)$

369 show HWE and are responsible for most genetic differentiation observed, particularly the

370 very low density one (C1 where all individuals have been sampled).

371 Recruitment is a spatially and temporally stochastic process: what is observed at 372 one site might represent only a single recruited cohort; whereas, at the neighbour site, 373 several distinct cohorts might have settled. When combined with the heterogeneity in the 374 genetic composition of recruits (due to difference in the source of recruits or to pre375 settlement selection), this suggests HWE and genetic originality may occur mostly in 376 infrequent recruiting sites. In contrast recruited pools made-up of an admixture of distinct 377 cohorts will exhibit linkage disequilibrium and departure from Hardy-Weinberg 378 equilibrium due to Wahlund effect, but allelic frequencies more homogeneous with that of 379 the population they come from.

The estimation of the putative number of genitors $\mathrm{N}_{\mathrm{g}}$ at the origin of a given spat 382 sample gives low values for all collectors, would we consider Takapoto or the whole 383 Tuamotu Gambier as a putative mother population. Trying to interpret those values in 384 terms of an absolute numerical estimation of $\mathrm{N}_{\mathrm{g}}$ would be risky because these are 385 calculated on the basis of $F$ st estimates that may have a large error variance. However, 
386 interesting information can be extracted from those data if one compares the different $\mathrm{N}_{\mathrm{g}}$

387 estimates involving different putative parents' genetic pools: a larger number is 388 systematically estimated while considering the whole Tuamotu- Gambier genetic pool as 389 putative parents' pool. This suggests that spat recruited in Takapoto represent an admixture 390 more representative of islands other than Northern Tuamotu-Gambier, and indicates that 391 the low number of parents at the origin of a given cohort is probably one of the factors 392 responsible for the heterogeneity of the genetic composition of recruits, as observed for the 393 closely related species P. maxima in Australia (Benzie and Smith-Keune 2006).

394 In conclusion, our data indicate that the spatio-temporal variability of spat 395 recruitment is accompanied by high spatio-temporal variability of the genetic composition 396 of recruits at local scale. Would this be an isolated observation, one may question the 397 generality of such finding, wondering about the possible influence of the large densities of 398 farmed stocks in Takapoto. However this fine scale "genetic patchiness", as described by 399 Johnsson et al. $(1982,1984)$, has been reported on a large range of non human-influenced 400 populations of marine invertebrates including gastropods (Campton et al. 1992; Johnson et 401 al. 1993; Holborn et al. 1994; Tatarenkov and Johannesson 1994), sea urchin (Watts et al. 402 1990; Edmands et al. 1996) and bivalves (Hedgecock 1994; David et al. 1997b; Benzie 403 and Smith-Keune 2006). Hedgecock proposed a "sweepstakes-chance matching 404 hypothesis", suggesting that in a heterogeneous and changing environment, young 405 succeeding in recruiting and surviving are the products of spawning by only a small 406 fraction of the adult population that spawned in the right windows of time and 407 environmental conditions. This hypothesis favours the importance of pre-settlement factors 408 at the origin of genetic mosaics in natural populations, rather than micro-environmental 409 post-settlement selection that has been demonstrated on one species of gastropods 410 (Johannesson et al. 1995). In other cases, the variation of the pattern over time as well as 
411 the chaotic distribution of genetic structure in space, suggested that pre-settlement factors

412 were more likely than post-settlement micro-environmental selection (Johnson and Black

413 1982; Johnson and Black 1984; Watts et al. 1990). In our case, the lack of consistence in 414 space and the genetic differentiation of collectors located close to each other suggest that

415 the "sweepstakes-chance matching hypothesis" is more likely to explain the genetic 416 patchiness observed than a post settlement selective process.

419 Implication for sampling and interpreting data in population genetics and biogeographic $420 \quad$ studies

422 This study illustrates a finding reported in several other benthic marine species: local 423 genetic structuring (several metres to several kilometres) sometimes reaching or exceeding 424 the differentiation reported at larger scale (hundreds to thousands kilometres). We have 425 highlighted that this apparent inconsistency is strongly related to the sampling design of 426 the study. The detection of genetic patchiness was only achieved by sampling in very 427 restricted areas compared to the ones that were explored (when such information was 428 available) when assessing large scale patterns and processes.

429 Chaotic genetic patchiness is now increasingly reported in marine invertebrates 430 (Jolly et al. 2003; Juinio-Menez et al. 2003; Casu et al. 2005; Virgilio and Abbiati 2006; 431 Virgilio et al. 2006; Andrade and Solferini 2007) and on fishes (Doherty et al. 1995; 432 Exadactylos et al. 1998; Planes et al. 2002; McPherson et al. 2003; Selkoe et al. 2006; 433 Burford and Larson 2007; Gonzalez-Wanguemert et al. 2007). Besides the evolutionary 434 and biological causes and implications of chaotic genetic patchiness, this phenomenon 435 becomes an issue when it comes to collecting a sample 'representative of the population 
436 studied'. All marine biologists face the problem of access to samples that is increasingly

437 difficult when studying a large-scale metapopulation system. It is seldom realistic to

438 expect an extremely sophisticated, hierarchically designed, and standardized sampling

439 scheme, particularly when working on sub-tidal and deep-sea organisms. Most of us have

440 to be content with a "statistically satisfying" number of samples collected, sometimes

441 including samples kindly provided by other researchers or local people, without the

442 minimum information as to the habitat, area covered, density of populations, etc. As a

443 result, only $33 \%$ of 68 studies dealing with population genetics of marine benthic

444 organisms gave indication as to the area and strategy of sampling in each population, and

$44557 \%$ did not give any indication of either the area explored, nor the choice of samples

446 collected. Technical and logistical difficulties may not allow much improvement in the

447 sampling we, as researchers, will have access to. However, the occurrence of genetic

448 patchiness should warn us against conclusions of genetic composition or limitations to

449 gene flow based on blind samples that depending on some characteristics of the sampling

450 sites (such as area explored or density) may reflect transient and localized genetic

451 patchiness rather than significant and long-term restriction to gene flow among localities 452 analyzed. 
457 Acknowledgements

458

459 We would like to thank all the people who helped us to collect samples: Terii Seaman and 460 Patrick Jilcot from the Pearl-Culture Service, Peva Levy, Claude Soyez, Marcel Matarere, 461 Destremeau Poroi, Herle Gorager and Johan Hamblin from Ifremer and Philippe Shoun. 462 We wish to address a very special thank to Gaby Hauamani, without whom none of the 463 work on spat would have been possible, and Vincent Prasil for useful discussions and 464 information about spat translocations. We thank Helen Boudry for help with the English in 465 this manuscript, and three anonymous referees for their useful comments and suggestions. 466 This work was supported in part by the "Contrat de développement $n^{\circ} 2$ 2000-2003 entre 467 l'Etat et le Territoire de Polynésie Française" and the BRG (Bureau des Ressources 468 Génétiques) 


\section{$471 \quad$ References}

472

473

474 Andrade SCS, Solferini VN (2007) Fine-scale genetic structure overrides macro-scale structure in a marine snail: nonrandom recruitment, demographic events or selection? Bio J of the Linn Soc 91: 23-36

Arnaud-Haond S, Bonhomme F, Blanc F (2003a) Large discrepancies in differentiation of allozymes, nuclear and mitochondrial DNA loci in recently founded Pacific populations of the pearl oyster Pinctada margaritifera. J Evol Biol 16: 388-398

Arnaud-Haond S, Boudry P, Saulnier D, Seaman T, Vonau V, Bonhomme F, Goyard E (2002) New anonymous nuclear DNA markers for the pearl oyster Pinctada margaritifera and other Pinctada species. Mol Ecol Notes 2: 220-222

Arnaud-Haond S, Vonau V, Bonhomme F, Boudry P, Prou J, Seaman T, Goyard E (2004) On the impact of cultural practices on genetic resources: evolution of the genetic composition of wild stocks of pearl oyster (Pinctada margaritifera cumingii) in French Polynesia after ten years of spat translocation. Mol Ecol 13: 2001-2007

Arnaud-Haond S, Vonau V, Bonhomme F, Boudry P, Prou J, Seaman T, Veyret M, Goyard E (2003b) Sustainable management of local genetic resources of the pearl oyster (Pinctada margaritifera cumingii) in French Polynesia: an evaluation of the potential impact of the cultural practice of spat collection. Aquaculture 219: 181192

Arndt A, Smith MJ (1998) Genetic diversity and population structure in two species of sea cucumber: differing pattern according to mode of development. Mol Ecol 7: 10531064 
495 Bassam BJ, Caetano-Anolles G, Greshof PM (1991) Fast and sensitive silver-staining of

496 DNA in polyacrylamide gels. Annals of Biochemistry 196: 80-83

497 Belkhir K, Borsa P, Chikhi L, N.Raufaste, Bonhomme F (1996-2001) GENETIX 4.02,

498 logiciel sous Windows TM pour la génétique des populations. Laboratoire Génome

499 et Populations, Interactions, Adaptations, CNRS UMR5000, Université Montpellier

$500 \quad$ II, Montpellier (France)

501 Benzie JAH (2000) The detection of spatial variation in widespread marine species:

502 methods and bias in the analysis of population structure in the crown of thorns

$503 \quad$ starfish (Echinodermata : Asteroidea). Hydrobiologia 420: 1-14

504 Benzie JAH, Smith-Keune C (2006) Microsatellite variation in Australian and Indonesian

505 pearl oyster Pinctada maxima populations. Mar Ecol Prog Ser 314: 197-211

506 Black WC, Krafsur ES (1985) A FORTRAN program for the calculation and analysis of

507 two-locus linkage disequilibrium coefficients. Theor App Gen 70: 491-496

508 Blanc F, Durand P, Shine-Milhaud M (1985) Genetic varability in populations of black

509 pearl oyster Pinctada margaritifera (Mollusque, Bivalve) de Polynésie. Proc. Fifth

$510 \quad$ International Coral Reefs Congress, Tahiti, 1985 4: 113-118

511 Bonhomme F, Planes S (2000) Some genetic arguments about what maintains the pelagic

512 phase in reef fishes. Env Biol of Fishes 59: 365-383

513 Boudry P, Collet B, Cornette F, Hervouet V, Bonhomme F (2002) High variance in

514 reproductive success of the Pacific oyster (Crassostrea gigas, Thunberg) revealed

515 by microsatellite-based parentage analysis of multifactorial crosses. Aquaculture

$516 \quad 204: 283-296$

517 Burford MO, Larson RJ (2007) Genetic heterogeneity in a single year-class from a

518 panmictic population of adult blue rockfish (Sebastes mystinus). Mar Biol 151:

$519 \quad 451-465$ 
520 Campton DE, Berg CJ, Robison LM, Glazer RA (1992) Genetic patchiness among

521 populations of queen conch Strombus gigas in the Florida keys and Bimini. Fish

$522 \quad$ Bull 90: 250-259

523 Casu M, Maltagliati F, Cossu P, Lai T, Galletti MC, Castelli A, Commito JA (2005) Fine-

524 grained spatial genetic structure in the bivalve Gemma gemma from Maine and

525 Virginia (USA), as revealed by Inter-Simple Sequence Repeat markers. J Exp Mar

$526 \quad$ Biol Ecol 325: 46-54

527 David P, Berthou P, Noel P, Jarne P (1997a) Patchy recruitment patterns in marine

528 invertebrates: a spatial test of the density-dependent hypothesis in the bivalve

$529 \quad$ Spisula ovalis. Oecologia 111: 331-340

530 David P, Perdieu M-A, Pernod A-F, Jarne P (1997b) Fine-Grained Spatial and Temporal

531 population genetic structure in the marine bivalve Spisula ovalis. Evolution 51 (4):

$532 \quad 1318-1322$

533 Desmarais E, Lannneluc I, Lagnel J (1998) Direct Amplification of Lenght Polymorphism

534 (DALP), or how to get and characterise new genetic markers in many species. Nucl

$535 \quad$ Ac Res 26(6): 1458-1465

536 Doherty PJ, Planes S, Mather P (1995) Gene Flow and Larval Duration in 7 Species of

537 Fish from the Great-Barrier-Reef. Ecology 76: 2373-2391

538 Durand P, Blanc F (1986) Divergence génétique chez un bivalve marin tropical: Pinctada

539 margaritifera. Coll Nat CNRS "Biologie des populations": 323-330

540 Edmands S, Moberg PE, Burton RS (1996) Allozyme and mitochondrial DNA evidence of

541 population subdivision in the purple sea urchin Strongylocentrotus purpuratus. Mar

$542 \quad$ Biol 126: 443-450

543 Exadactylos A, Geffen AJ, Thorpe JP (1998) Population structure of the Dover sole, Solea

544 solea L., in a background of high gene flow. J Sea Res 40: 117-129 
545 Friedman KJ, Bell JD (1999) Variation in abundance of blacklip pearl oyster (Pinctada

546 margaritifera Linne.) spat from inshore and offshore reefs in Solomon islands.

$547 \quad$ Aquaculture 178: 273-291

548 Friedman KJ, Bell JD, Tiroba G (1998) Availability of wild spat of the blacklip pearl

549 oyster, Pinctada margaritifera, from "open" reef systems in Solomon islands.

$550 \quad$ Aquaculture 167: 283-299

551 Gaines SD, Bertness MD (1992) Dispersal of juveniles and variable recruitment in sessile

552 marine species. Nature 360: 579-580

553 Gonzalez-Wanguemert N, Perez-Ruzafa A, Canovas F, Garcia-Charton JA, Marcos C

554 (2007) Temporal genetic variation in populations of Diplodus sargus from the SW

$555 \quad$ Mediterranean Sea. Mar Ecol Prog Ser 334: 237-244

556 Hedgecock D (1994) Does variance in reproductive success limit effective population size

557 of marine organisms? Genetics and Evolution of Aquatic Organisms: 122-134

558 Hellberg ME (1996) Dependence of gene flow on geographic distance in two solitary

$559 \quad$ corals with different larval dispersal abilities. Evolution 50(3): 1167-1175

560 Holborn K, Johnson MS, Black R (1994) Population genetics of the corralivorous

561 gastropod Drupella cornus at Ningaloo reef, Western Australia. Coral Reefs 13:

$562 \quad 33-39$

563 Hoskin MG (1997) Effects of contrasting modes of larval development on the genetic

564 structures of populations of three species of prosobranch gastropods. Mar Biol 127:

$565 \quad 647-656$

566 Hunt A (1993) Effects of contrasting patterns of larval dispersal on the genetic

567 connectedness of local populations of two intertidal starfish, Patiriella calcar and

568 P. exigua. Mar Ecol Prog Ser 92: 179-186 
569 Johannesson K, Johannesson B, Lundgren U (1995) Strong natural-selection causes

570 microscale allozyme variation in a marine snail. Proc Nat Ac Sci USA 92: 2602-

$571 \quad 2606$

572 Johnson MS, Black R (1982) Chaotic Genetic Patchiness in an Intertidal Limpet, $573 \quad$ Siphonaria sp. Mar Biol 70: 157-164

574 Johnson MS, Black R (1984) Pattern beneath the chaos: the effect of recruitment on 575 genetic patchiness in an intertidal limpet. Evolution 38: 1371-1383

576 Johnson MS, Holborn K, Black R (1993) Fine-scale patchiness and genetic heterogeneity

577 of recruits of the corralivorous gastropod Drupella cornus. Mar Biol 117: 91-96

578 Johnson MS, Wernham J (1999) Temporal variation of recruits as a basis of ephemeral 579 genetic heterogeneity in the western rock lobster Panulirus cygnus. Mar Biol 135:

$580 \quad 133-139$

581 Jolly MT, Viard F, Weinmayr G, Gentil F, Thiebaut E, Jollivet D (2003) Does the genetic 582 structure of Pectinaria koreni (Polychaeta : Pectinariidae) conform to a source583 sink metapopulation model at the scale of the Baie de Seine? Helgoland Mar Res $584 \quad 56: 238-246$

585 Juinio-Menez MA, Magsino RM, Ravago-Gotanco R, Yu ET (2003) Genetic structure of 586 Linckia laevigata and Tridacna crocea populations in the Palawan shelf and shoal 587 reefs. Mar Biol 142: 717-726

588 Li G, Hedgecock D (1998) Genetic heterogeneity, detected by PCR-SSCP, among samples 589 of larval Pacific oysters (Crassostrea gigas) supports the hypothesis of large $590 \quad$ variance in reproductive success. Can J Fish Aquat Sci 55: 1025-1033

591 McPherson AA, Stephenson RL, Taggart CT (2003) Genetically different Atlantic herring 592 Clupea harengus spawning waves. Mar Ecol Prog Ser 247: 303-309 
593 McShane PE, Smith MG (1991) Recruitment variation in sympatric populations of

594 Haliotis rubra (Mollusca: Gastropoda) in southeast Australian waters. Mar Ecol

$595 \quad$ Prog Ser 73: 203-210

596 Nei M (1987) Molecular evolutionary geneticsColumbia Univ. Press, New York

597 Palumbi SR (1995) Nucleic acids II: The polymerase chain reaction. In: D. Hillis and C.

598 Moritz e (ed) Molecular systematics, Sinauer, Sunderland, Massachusetts, pp 205-

$599 \quad 247$

600 Paulay G (1990) Effects of late Cenozoic sea-level fluctuations on the bivalve faunas of

$601 \quad$ tropical oceanic islands. Paleobiology 16: 401-434

602 Peel D, Ovenden JR, Peel SL (2004) NeEstimator: software for estimating effective

603 population size,. Department of Primary Industries and Fisheries., Queensland

$604 \quad$ Government

605 Planes S, Fauvelot C (2002) Isolation by distance and vicariance drive genetic structure of

606 a coral reef fish in the Pacific Ocean. Evolution 56: 378-399

607 Planes S, Galzin R, Bonhomme F (1996) A genetic metapopulation model for reef fishes

608 in oceanic islands: the case of the surgeonfish, Acanthurus triostegus. J Evol Biol

609 9: $103-117$

610 Planes S, Lecaillon G, Lenfant P, Meekan M (2002) Genetic and demographic variation in

611 new recruits of Naso unicornis. J Fish Biol 61: 1033-1049

612 Poulin E, Féral J-P (1996) Consequences of brood protection on the diversity of antarctic

613 echinoids. Evolution 50: 820-830

614 Roughgarden J, Gaines S, Possingham H (1988) Recruitment dynamics in complex life

$615 \quad$ cycles. Science 241: 1460-1466

616 Sambrook J, Fritsch EF, Maniatis T (1989) Molecular cloning, $2^{\text {nd }}$ edition. Cold Spring

617 Harbor laboratory. Cold Spring Harbor, N. Y. 
618 Selkoe KA, Gaines SD, Caselle JE, Warner RR (2006) Current shifts and kin aggregation

619 explain genetic patchiness in fish recruits. Ecology 87: 3082-3094

620 Tatarenkov A, Johannesson K (1994) Habitat related allozyme variation on a

621 microgeographic-scale in the marine snail Littorina mariae (Prosobranchia,

$622 \quad$ Littorinacea). Bio J Linn Soc 53: 105-125

623 Vermeij G (1987) The dispersal barrier in the tropical Pacific: implications for molluscan

$624 \quad$ speciation and extinction. Evolution 41: 1046-1058

625 Virgilio M, Abbiati M (2006) Temporal changes in the genetic structure of intertidal

626 populations of Hediste diversicolor (Polychaeta : Nereididae). J Sea Res 56: 53-58

627 Virgilio M, Backeljau T, Abbiati M (2006) Mitochondrial DNA and allozyme patterns of

628 Hediste diversicolor (Polychaeta : Nereididae): the importance of small scale

629 genetic structuring. Mar Ecol Prog Ser 326: 157-165

630 Waples RS (1989) A generalized approach for estimating effective population size from

631 temporal changes in allele frequency. Genetics 121: 379-391

632 Watts RJ, Johnson MS, Black R (1990) Effects of recruitment on genetic patchiness in the

633 urchin Echinometra mathaei in Western Australia. Mar Biol 105: 145-151

634 Weir BS (1979) Inferences about linkage disequilibrium. Biometrics 35: 235-254

635 Weir BS, Cockerham CC (1984) Estimating F-statistics for the analysis of populations

$636 \quad$ structure. Evolution 38(6): 1358-1370

637

638

639 
640 Table 1 : Sample size (N), geographic location in the lagoon (see Fig 2), number of

641 alleles, expected $\left(\mathrm{H}_{\mathrm{nb}}\right)$ and observed $\left(\mathrm{H}_{\mathrm{obs}}\right)$ heterozygosity, and heterozygote deficiency

$642\left(\mathrm{~F}_{\text {is }}\right) *$ significant after a permutation test (1000 permutations).

643

\begin{tabular}{ccccccccc}
\hline archipelagos & sample & & area & $\mathrm{N}$ & Alleles & $\mathrm{H}_{\mathrm{nb}}$ & $\mathrm{H}_{\mathrm{obs}}$ & $\mathrm{F}_{\text {is }}$ \\
& & Samples & & & $\mathrm{Nb}$ & & & \\
\hline \multirow{5}{*}{ Society } & Manuae & MA & - & 23 & 3.00 & 0.304 & 0.268 & 0.118 \\
& Maupihaa & MP & - & 40 & 4.25 & 0.364 & 0.266 & $0.273^{*}$ \\
& Arutua & AR & - & 28 & 3.25 & 0.376 & 0.314 & $0.167^{*}$ \\
& Manihi & MH & - & 22 & 3.25 & 0.377 & 0.263 & $0.307^{*}$ \\
& Apataki & AI & $1 \mathrm{~km}^{2}$ & 28 & 3.75 & 0.359 & 0.372 & 0.092 \\
& Hereheretue & HERE & $>10 \mathrm{~km}^{2}$ & 27 & 5.00 & 0.397 & 0.369 & 0.071 \\
& Takaroa & TA & - & 30 & 3.50 & 0.339 & 0.303 & 0.108 \\
& Raroia & RA & - & 15 & 3.25 & 0.406 & 0.293 & $0.285^{*}$ \\
& Kauehi & KA & - & 19 & 3.75 & 0.451 & 0.3691 & 0.188 \\
& Makemo & MK & - & 28 & 3.25 & 0.410 & 0.366 & 0.109 \\
Makapoto beds & Hao & HAO & $0.06 \mathrm{~km}^{2}$ & 12 & 2.50 & 0.355 & 0.275 & 0.234 \\
& Marutea & MRT & $0.4 \mathrm{~km}^{2}$ & 29 & 3.00 & 0.323 & 0.294 & 0.094 \\
& Mangareva & MG & $4 \mathrm{~km}^{2}$ & 40 & 3.75 & 0.368 & 0.323 & $0.125^{*}$ \\
& Nuku Hiva & NH & $>10 \mathrm{~km}^{2}$ & 42 & 3.00 & 0.396 & 0.353 & 0.111 \\
& Hiva Oa & HO & $>10 \mathrm{~km}^{2}$ & 31 & 2.75 & 0.389 & 0.378 & 0.029 \\
& Takapoto 1 & Tkp1 & 1 & 37 & 3.75 & 0.342 & 0.212 & $0.383^{*}$ \\
& Takapoto 2 & Tkp2 & 2 & 54 & 3.75 & 0.346 & 0.300 & 0.138 \\
& Takapoto 3 & Tkp3 & 3 & 29 & 4.25 & 0.366 & 0.315 & 0.142 \\
Takapoto collectors & Collecteur 1 & C1 & C & 37 & 4.00 & 0.294 & 0.252 & 0.144 \\
& Collecteur 2 & C2 & B & 52 & 3.75 & 0.365 & 0.242 & $0.338^{*}$ \\
& Collecteur 3 & C3 & B & 41 & 3.50 & 0.382 & 0.374 & 0.021 \\
& Collecteur 4 & C4 & A & 50 & 3.50 & 0.360 & 0.240 & $0.283^{*}$ \\
& Collecteur 5 & C5 & A & 50 & 4.00 & 0.392 & 0.282 & $0.148^{*}$ \\
& Collecteur 6 & C6 & A & 50 & 4.00 & 0.404 & 0.344 & $0.336^{*}$ \\
\hline 644 & & & & & & & &
\end{tabular}


Table 2: $F_{\mathrm{ST}}$ values for pairwise comparison among samples from wild populations from $P$. margaritifera, based on four anonymous nuclear DNA markers. Abbreviations for samples are as detailed in Table 1. Significant values after the 1000 permutation test are in bold.

\begin{tabular}{|c|c|c|c|c|c|c|c|c|c|c|c|c|c|c|c|}
\hline \multirow{2}{*}{$\begin{array}{c}\text { Archipelag } \\
\text { os } \\
\end{array}$} & \multicolumn{11}{|c|}{ Tuamotu-Gambier } & \multicolumn{2}{|c|}{ Society } & \multicolumn{2}{|c|}{ Marquesas } \\
\hline & AR & MH & AI & KA & TA & HERE & RA & MK & HAO & MRT & MG & MA & MP & $\mathrm{NH}$ & $\mathrm{HO}$ \\
\hline AR & - & 0.000 & 0.004 & 0.002 & 0.011 & 0.010 & -0.005 & 0.001 & -0.016 & 0.031 & 0.014 & 0.027 & 0.024 & 0.003 & 0.049 \\
\hline MH & & - & -0.013 & -0.016 & -0.009 & -0.014 & -0.016 & 0.015 & -0.018 & 0.015 & 0.014 & -0.014 & -0.004 & 0.011 & 0.080 \\
\hline AI & & & - & 0.006 & 0.001 & 0.009 & -0.012 & 0.013 & -0.024 & 0.002 & 0.002 & -0.008 & -0.001 & 0.025 & 0.085 \\
\hline $\mathrm{KA}$ & & & & - & 0.006 & -0.014 & -0.013 & 0.012 & -0.011 & 0.040 & 0.031 & 0.007 & 0.007 & 0.020 & $\mathbf{0 . 0 8 0}$ \\
\hline TA & & & & & - & 0.009 & -0.005 & 0.004 & -0.014 & 0.005 & 0.015 & -0.007 & -0.006 & 0.011 & 0.056 \\
\hline HERE & & & & & & - & -0.006 & 0.029 & 0.006 & 0.048 & 0.042 & 0.001 & 0.011 & 0.032 & 0.105 \\
\hline RA & & & & & & & - & -0.005 & -0.029 & -0.000 & -0.005 & 0.005 & -0.009 & 0.017 & 0.069 \\
\hline MK & & & & & & & & - & -0.021 & 0.013 & 0.006 & 0.030 & 0.020 & 0.027 & 0.017 \\
\hline HAO & & & & & & & & & - & -0.015 & -0.012 & -0.008 & 0.007 & -0.000 & 0.041 \\
\hline MRT & & & & & & & & & & - & 0.000 & 0.004 & 0.011 & 0.029 & 0.067 \\
\hline MG & & & & & & & & & & & - & 0.023 & 0.023 & 0.016 & 0.046 \\
\hline MA & & & & & & & & & & & & - & -0.007 & 0.036 & 0.102 \\
\hline MP & & & & & & & & & & & & & - & 0.022 & 0.078 \\
\hline $\mathrm{NH}$ & & & & & & & & & & & & & & - & 0.014 \\
\hline $\mathrm{HO}$ & & & & & & & & & & & & & & & - \\
\hline
\end{tabular}


Table 3 : Significant correlations $(\mathrm{R})$ between allelic frequencies at the different loci, per loci pair in all the spat and wild samples. $* \mathrm{P}<0,05$, $* * \mathrm{P}<0,01$. No significant value was observed for the other natural populations.

\begin{tabular}{lcccccccc}
\hline Pair & Tkp3 & C1 & C2 & C3 & C4 & C5 & C6 & Total \\
\hline Pin2-pin3 & - & - & - & $\mathbf{0 . 4 3} * *$ & $0.09^{*}$ & - & - & - \\
Pin2-Pinaldo & - & - & $\mathbf{0 . 1 9 * *}$ & $\mathbf{0 . 2 9 * *}$ & - & - & $0.13^{* *}$ & - \\
Pin2-PinU4 & - & - & $\mathbf{0 . 1 8 * *}$ & - & - & $0.20^{*}$ & $\mathbf{0 . 1 8 * *}$ & - \\
Pin3-Pinaldo & $\mathbf{0 . 2 6 * *}$ & - & - & - & - & - & - & - \\
Pin3-PinU4 & - & - & - & - & - & - & - & - \\
Pinaldo-PinU4 & - & - & - & - & - & - & - & - \\
\hline
\end{tabular}


Table 4 : Detail of pairwise $F_{\mathrm{ST}}$ estimates of the genetic differentiation. Significant values after the permutation test (1000 permutations) are indicated in bold.

\begin{tabular}{|c|c|c|c|c|c|c|c|c|c|c|c|c|}
\hline$F \mathrm{ST}$ & $\mathrm{Ma}$ & Ap & $\mathrm{Tkr}$ & Tkp 1 & Tkp 2 & Tkp 3 & $\mathrm{C} 1$ & C 2 & C 3 & $\mathrm{C} 4$ & C 5 & C 6 \\
\hline Arutua & 0,000 & 0,004 & 0,012 & 0,009 & 0,019 & 0,034 & 0,049 & 0,009 & $-0,007$ & 0,013 & 0,009 & 0,018 \\
\hline Manihi & - & $-0,013$ & $-0,010$ & $-0,003$ & 0,007 & 0,009 & $\mathbf{0 , 0 2 8}$ & $-0,012$ & 0,000 & $-0,022$ & $-0,002$ & $-0,009$ \\
\hline Apataki & & - & $-0,003$ & 0,002 & $-0,005$ & 0,003 & 0,012 & $-0,006$ & 0,003 & $-0,002$ & $-0,003$ & 0,008 \\
\hline Takaroa & & & - & 0,023 & 0,013 & 0,016 & 0,008 & $-0,001$ & 0,001 & 0,001 & 0,003 & $-0,007$ \\
\hline Takapoto 1 & & & & - & 0,011 & $\mathbf{0 , 0 2 9}$ & 0,054 & 0,005 & 0,018 & 0,010 & 0,015 & $\mathbf{0 , 0 3 3}$ \\
\hline Takapoto 2 & & & & & - & $-0,005$ & $\mathbf{0 , 0 3 2}$ & 0,006 & 0,019 & 0,015 & 0,000 & 0,029 \\
\hline Takapoto 3 & & & & & & - & 0,034 & 0,014 & 0,032 & 0,020 & 0,009 & $\mathbf{0 , 0 2 7}$ \\
\hline Collecteur1 & & & & & & & - & $\mathbf{0 , 0 2 3}$ & $\mathbf{0 , 0 2 3}$ & $\mathbf{0 , 0 3 9}$ & 0,026 & 0,015 \\
\hline Collecteur2 & & & & & & & & - & 0,007 & $-0,001$ & 0,004 & 0,009 \\
\hline Collecteur 3 & & & & & & & & & - & 0,013 & 0,004 & 0,004 \\
\hline Collecteur 4 & & & & & & & & & & - & 0,008 & 0,003 \\
\hline Collecteur 5 & & & & & & & & & & & - & 0,009 \\
\hline Collecteur 6 & & & & & & & & & & & & - \\
\hline
\end{tabular}


Table 5 : Estimation of the average $\left(N_{\mathrm{e}}\right)$, maximum (max, $\left.\mathrm{P}<0.975\right)$ and minimum (min, $\mathrm{P}<0.025)$ number of genitors of the cohorts sampled in the different collectors $N_{\mathrm{e}} \max _{\min }$, using as a putative parental group the samples from Takapoto $1,2,3$, the average of these three samples, and the average of all samples from samples from Tuamotu (Apataki, Manihi, Arutua and Takaroa).

\begin{tabular}{lcccccc}
\hline sample & $N_{\mathrm{e}}$ & Tkp 1 & Tkp 2 & Tkp 3 & Takapoto & Tuamotu \\
\hline Collecteur 1 & 37 & $16_{5}^{93}$ & $13_{4}^{47}$ & $11_{4}^{43}$ & $18_{6}^{59}$ & $57_{13}^{\infty}$ \\
Collecteur 2 & 52 & $14_{5}^{59}$ & $12_{4}^{36}$ & $10_{4}^{33}$ & $18_{7}^{48}$ & $41_{12}^{382}$ \\
Collecteur 3 & 41 & $14_{4}^{79}$ & $9_{3}^{23}$ & $8_{3}^{21}$ & $12_{5}^{31}$ & $132_{17}^{\infty}$ \\
Collecteur 4 & 50 & $15_{43}^{69}$ & $12_{4}^{43}$ & $11_{3}^{40}$ & $20_{7}^{65}$ & $79_{16}^{\infty}$ \\
Collecteur 5 & 50 & $14_{4}^{49}$ & $35_{6}^{\infty}$ & $15_{5}^{75}$ & $30_{10}^{136}$ & $37_{12}^{270}$ \\
Collecteur 6 & 50 & $11_{4}^{36}$ & $9_{3}^{24}$ & $9_{3}^{28}$ & $13_{5}^{34}$ & $46_{22}^{14381}$ \\
\hline
\end{tabular}


Figure 1: Localization of the Polynesian islands where samples were collected, on the three principals archipelagoes from French Polynesia: Society, Tuamotu-Gambier and Marquesas.

Figure 2: Map of the Takapoto lagoon, indicating the spat collection stations (with high and homogeneous density: A, and low and heterogeneous density : B and C), where samples were collected (respectively 3, 2, and 1 spat collector sampled). Sampling zones of wild beds are also indicated (1, 2 and 3).

Figure 3: Results of the literature survey for sampling details and strategy.

Appendix : list of articles screened for sampling strategy 
Click here to download high resolution image

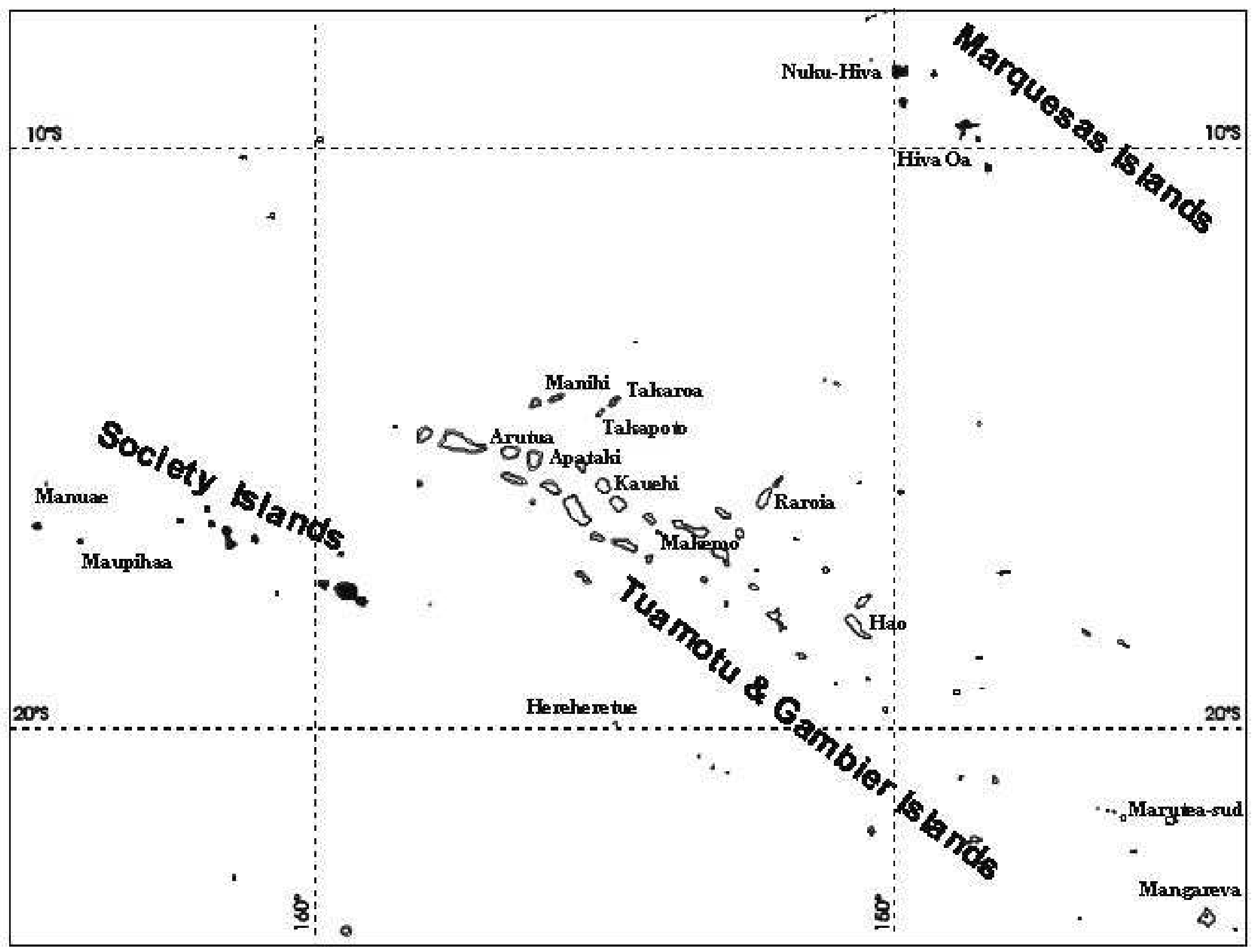


Click here to download high resolution image

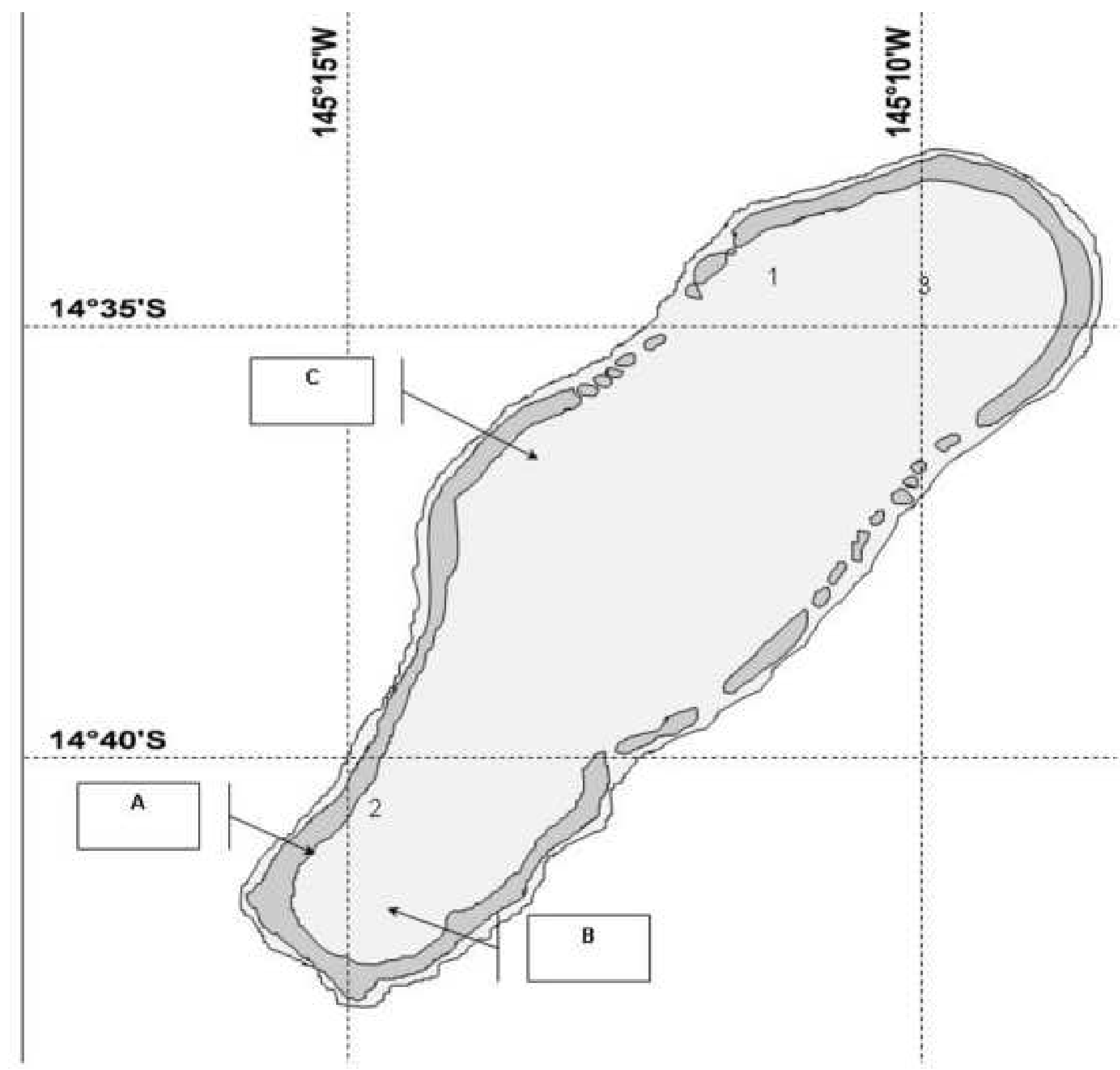




\section{$\%$ studies}

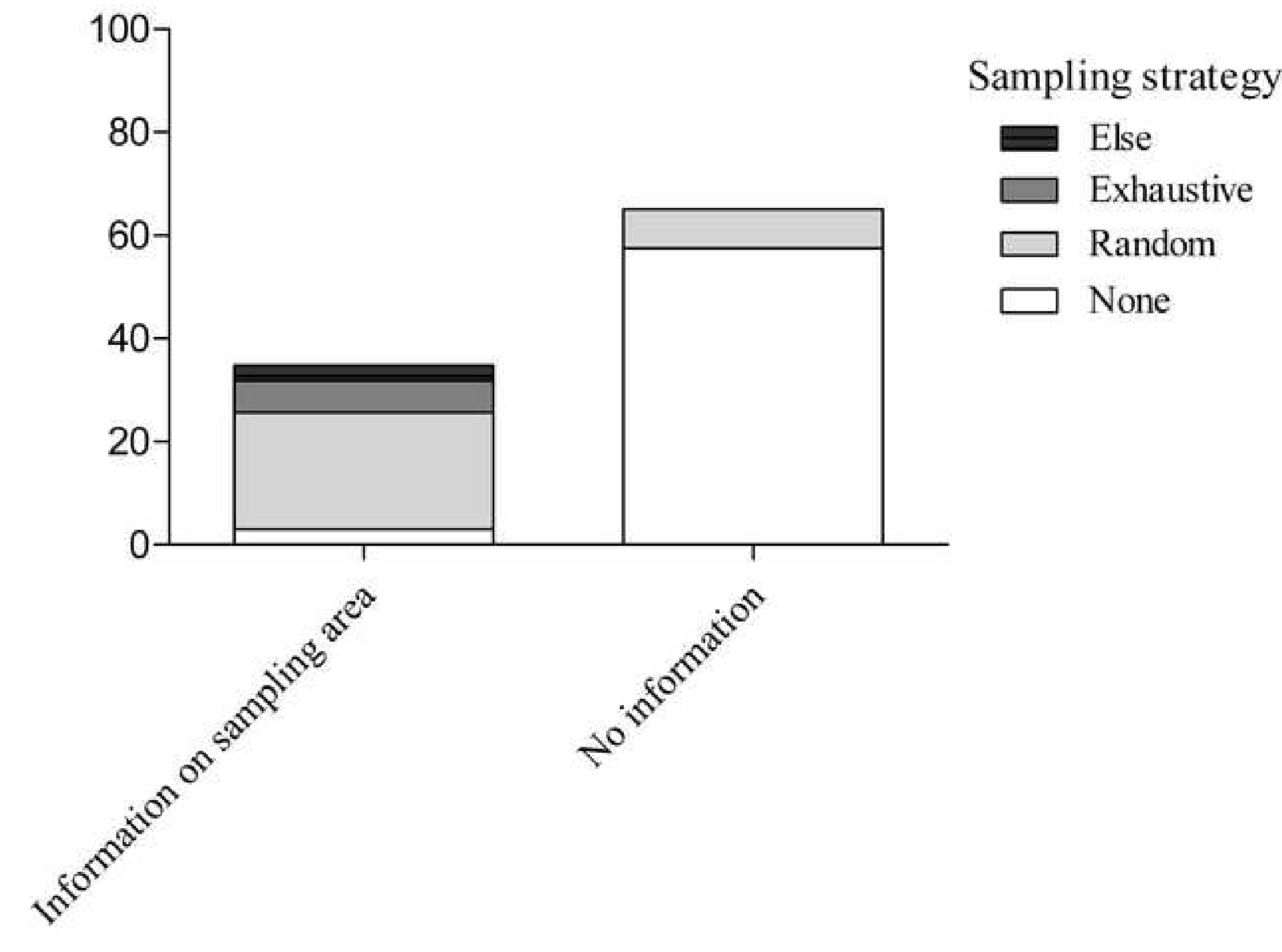

Sampling strategy

Else

$\square$ Exhaustive

$\square$ Random

$\square$ None 